2012

\title{
International Financial Standards and the Explanatory Force of Lex Mercatoria
}

Cally Jordan

MelbourneLaw School, c.jordan@unimelb.edu.au

Center for Transnational Legal Studies Research Paper No. 12-120

This paper can be downloaded free of charge from:

http://scholarship.law.georgetown.edu/ctls_papers/3

http://ssrn.com/abstract $=2107943$

The author is also affiliated with the European Corporate Governance Institute (ECGI) and the Center for Transnational Legal Studies (London). 
July 24, 2012

\title{
International Financial Standards and the Explanatory Force of Lex Mercatoria
}

\author{
Cally Jordan
}

\author{
Melbourne Law School \\ European Corporate Governance Institute
}

\begin{abstract}
The global financial crisis has cast a strong light on some hitherto obscure corners of the financial world, provoking an outpouring of calls for concerted international action.

"Hard law" having disappointed, can "soft law", in the form of international financial standards, substitute for traditional national legislation. This article examines some of the difficulties associated with the "international standards as soft law" discourse.

First of all, conceptual problems in the "soft law" discourse itself reveal profoundly different patterns of legal thought cutting across national boundaries, resulting in different understandings of international financial standards. Secondly, recent experience, over the past decade, with some "soft law" international financial standards as both diagnostic and prophylactic tools, has been decidedly mixed, in fact, largely unsatisfactory. Thirdly, the "soft law" discourse in international finance appears strangely remote from the daily grind of international commercial practice, where the discourse is largely unknown. But perhaps in this disconnect between theory and practice lies clues to important normative forces at work in international finance, and in particular the international capital markets. The more one considers the world of international finance, the more obvious become the outlines of centuries old transnational merchant law, the contentious lex mercatoria.
\end{abstract}


The proposition put forward here is that the formal regulation of financial markets is supported by a body of strong and persistent customary law, a lex mercatoria, a rarely acknowledged but powerful undercurrent in finance, especially in its international iteration. The continued prevalence of oral contracting and the stubborn persistence of self-regulatory principles are examples.

There are several intriguing implications to this proposition. Is it possible that the global financial crisis represented not only a failure of formal, state-led regulation, as it surely did, but also a breakdown of a lex mercatoria of finance? If that is the case, international standard setters and national regulators, both, ignore this lex mercatoria (the customs and practices of international finance) at their peril. To do so, would be to miss a true, powerful, source of normativity operating in international financial market.s

July 24,2012

\title{
International Financial Standards and the Explanatory Force of Lex Mercatoria
}

\author{
Cally Jordan
}

Melbourne Law School

European Corporate Governance Institute

\section{Introduction}

I. Differing Patterns of Legal Thought and the "Soft Law" Discourse

II. International Financial Standards
A. The Role of the FSF and the FSAP
B. Inadequacies of the FSAP Experience

III. International Commercial Practice and Soft Law 


\section{International Capital Markets and the Lex Mercatoria}

A. What is lex mercatoria

B. The Persistence of the lex mercatoria

1. The City of London and Self-Regulation

2. The Case of Oral Contracts

\section{Modern Finance and the lex mercatoria}

\section{Conclusion}

\section{Introduction}

The global financial crisis has cast a strong light on some hitherto obscure corners of the financial world, ${ }^{1}$ provoking an outpouring of calls for concerted international action. Suddenly, or so it seems, there has been a surge of interest in international financial standards and the various international bodies associated with creating and implementing them. $^{2}$ A new discourse looks to gradations of normativity, "soft" through "hard" law, and points in-between, such as "coercive soft law". "Hard law" having disappointed, can "soft law", in the form of international standards, substitute for or augment traditional national legislation. "Soft law", a conceptual spillover from the world of international public law, of treaties and governments, has entered the realm of international private law.

\footnotetext{
${ }^{1}$ Eg., the current scandal involving the possible manipulation of LIBOR, the London Interbank Offered Rate. See Michael Mackenzie, Libor probe shines light on voice brokers, FINANCIAL TIMES (LONDON), February 16, 2012.

2 See, eg., Chris Brummer, How International Financial Law Works (and How it Doesn't), 99 Georgetown L.J.257 (2011); Eilis Ferran \& Kern Alexander, Can Soft Law Bodies be Effective? Soft Systemic Risk Oversight Bodies and the Special Case of the European Systemic Risk Board, 35 EuROPEAN L. R. 751 (2010).

${ }^{3}$ See discussion in Brummer, id, fn 113 citing Andrew Guzman \& Timothy L. Meyer, Explaining Soft Law.(work in progress )(2009).
} 
This discourse, however, is problematic at several levels. There are conceptual problems in the "soft law" discourse itself, that reveal profoundly different patterns of legal thought cutting across national boundaries. US academics appear to be struggling with definitional difficulties, ${ }^{4}$ caught on the seesaw of law necessarily emanating from the state and judicially enforceability The English common law, a customary law to this day, is much more comfortable with more diffuse sources of law and less fixated on the state. And some continental jurists may rarely give judicial enforcement a second thought.

Secondly, recent experience, over the past decade, with some international financial standards, as both diagnostic and prophylactic tools, has been decidedly mixed, in fact, largely unsatisfactory. Looking to international standards, in their current form, particularly in the area of capital markets, as an effective means of addressing systemic failings may be unproductive.

Thirdly, the "soft law" discourse in international finance appears strangely remote from the daily grind of international commercial practice, where the discourse is largely unknown. International commercial practitioners do not much think about state authority or judicial enforcement in going about their business. Their analyses are granular; a reference to "international financial law" would evoke bewilderment, as being devoid of meaning. The efforts of international practitioners are focused on promoting effectiveness; concerns as to judicial enforcement are far down the list.

But perhaps in this disconnect between theory and practice lie clues to the normative forces at work in international financial markets, and how best to harness them. International finance has a long history, its roots extending back centuries, even millennia, predating the "hard law" of nation state and its courts. For some comparativists, the "hard law" of rules finds its normative force, not in the state and its

\footnotetext{
${ }^{4}$ See Guzman \& Meyer, International Soft Law ,2 J. of LEgAl AnaLYSIS 171 (2010)
} 
courts, but rather in the, for want of a better word, customary law upon which it draws. ${ }^{5}$ The more one considers the world of international finance, where commercial practice has operated for centuries in the absence of, or despite, national law, the more obvious become the outlines of financial customary law.

The proposition put forward here is that the formal regulation of financial markets is supported by a body of customary law, a lex mercatoria, a rarely acknowledged but powerful undercurrent in finance, especially in its international iteration. This lex mercatoria demonstrates persistence and continuity, stretching back centuries, and it is neither "hard" nor "soft" as is understood in the current discourse.

There are several intriguing implications to this proposition. Is it possible that the global financial crisis represented not only a failure of formal, state-led regulation, as it surely did, but also a breakdown of a lex mercatoria of finance? If that is the case, international standard setters and national regulators, both, ignore this lex mercatoria (the customs and practices of international finance) at their peril. To do so, would be to miss a true, powerful, source of normativity operating in international financial markets

Further, are international financial standard setters, in their efforts, attempting to recreate a lex mercatoria of finance? Do we need international financial standards at all, or just better lex mercatoria? Will the current waves of regulation push the lex mercatoria into hiding? Or, on the contrary, will regulatory turbulence and impasses promote the blossoming of new forms of international practices?

The first part of this paper looks to the differing patterns of legal thought which cut across national boundaries and the implications for the "soft law" discourse in the context of international financial standards. The second part of the paper examines the recent misadventures involving "soft law" international financial standards in the capital markets. The third part of the part looks at some of the characteristics of international

5 See, eg., the interesting discussion in Walter Weyrauch \& Marueen Bell, Autonomous Lawmaking: The Case of the "Gypsies", 103 YALE L.J. 323 (1993-1994) on "State Law vs Private Lawmaking " at pp $326 \mathrm{ff}$. 
commercial practice that demonstrative the multiplicity of normativity at work. The last part of the paper looks at international capital markets from the perspective of a lex mercatoria and the implications flowing from this.

\section{Differing Patterns of Legal Thought and the "Soft Law" Discourse}

Academics in the United States appear to be struggling with definitional difficulties, ${ }^{6}$ caught on the seesaw that law must emanate from the state and be judicially enforceable. The English common law, on the other hand, is comfortable with more diffuse sources of law, with less fixation on the state. And some continental jurists may instinctively regard judicial enforcement as less than significant in the larger scheme of things.

Formal written law, and its judicial enforcement, are imprinted on the US legal psyche. Beyond these boundaries lies lawlessness. The dominance of written law and judicial enforcement is indicative of the two great historical sources of US law: the English common law as wrought by an 18thC judiciary and European civilian thinking of the immediate post revolutionary period.

Great deference is paid to the judiciary in the United States and procedure dominates substance. One of the finest commercial courts in the world is the Delaware Court of Chancery, which, having deliberately adopted the jurisdiction of its English counterpart in post-revolutionary days of 1792 , continues, almost alone in the world, to exercise a very pure form of equitable jurisdiction.

On the other hand, the United States is also, in the European tradition, a land of written law, formal statutory law and regulation, in a way which the UK decidedly is not. In the United States, there is no aversion to written law; there is lots of it. In the view of $\mathrm{H}$. Patrick Glenn, this constitutes the "particular genius" 7 of the US legal system, "its constructive combination of elements of both civil and common law."8 Because language and history bind America and England, the legacy of the English judiciary has

${ }^{6}$ See Guzman \& Meyer, "International Soft Law" , supra note 3.

7 H. PATRick GLENN, LEgal Traditions OF THE WorLd 248, 251 (2d ed. 2004).

${ }^{8}$ Id. 
remained at the surface, readily observable, resulting in the characterization of the United States as a "common law" jurisdiction.

But is it really? The US legal system is certainly unlike others found in the Commonwealth. ${ }^{9}$ According to Glenn, in "many respects US law represents a deliberate rejection of common law principles, with preference being given to more affirmative ideas clearly derived from civil law. These were not somehow reinvented in the United States but taken over directly from civilian sources in a massive process of change in adherence to legal information in the nineteenth century." 10

Like that of France, the US legal system is the product of revolution, symbolizing a break with what came before. In the case of the United States, the legal system and the state are conjoined twins, born together and inextricably linked by the Constitution. ${ }^{11}$

The US seesaw, balancing formal legislation against judicial enforcement, is apparent in much of the modern US-influenced discourse on law and development, for example. In large measure due to the geo-political forces at work, the period subsequent to the breakup of the former Soviet Union saw a massive transplantation of US-style legislation in Central Europe and East Asia. ${ }^{12}$ When this "good law", this legislation, proved ineffective (or did not behave quite as expected), there were immediate calls for better judicial enforcement (and training of the judiciary to do it).

In the United Kingdom, statutory law, written law, has traditionally been a second best solution, a last, uncomfortable, resort, representing a failure of the common law. The prospect of codification is even more chilling in the UK, giving rise to atavistic visions of guillotines and burning barricades. Arguably, all this has changed, at least superficially, with the entry of the UK into the European Union and the massive realignment of English statutory law to the dictates of Brussels.

\footnotetext{
${ }^{9}$ Except, perhaps, for Canada which has been subject to the beneficent influences of the Napoleonic Code through Quebec, and later direct statutory and judicial influences from the United States itself. 10 Glenn, supra note 6, 248.

${ }^{11}$ One might say that, ultimately, all law in the United States is constitutional law.

${ }^{12}$ A similar wave of US style legislation crashed upon former combatant countries in the Asia-Pacific after World War II.
} 
These different patterns of legal thought are at the heart of the trans-Atlantic debate of the last decade as to the superiority of one or the other of two different approaches to financial regulation, rules-based or principles-based. It also explains the popularity in the UK of "voluntary" codes of commercial behaviour (and the difficulty of transplanting them elsewhere) and "comply or disclose" as a regulatory technique. ${ }^{13}$ Principles-based regulation and voluntary codes of conduct, however, do not operate in a vacuum in the UK; they derive their normative and operational force from common, but non-statutory, understandings of commercial behaviour.

In many of the codal countries of continental Europe, the judiciary, of course, plays a different, much subsidiary, role than in the UK or the United States. The triumvirate of the written word, doctrine, code and statute, are more authoritative.

In different ways, both the UK and the rest of Europe are thus open to concepts of international standards, transnational norms, in a way in which the United States may not be. From the UK perspective, such norms may represent an extension, internationally, of principles based, voluntary codes provided they are rooted in and informed by commercial realities. From the European perspective, the fact that such norms are written gives them inherent authority, irrespective of their provenance, state or otherwise. ${ }^{14}$

But in the United States, "law" revolves around the twin stars of formal legislation and judiciary, only occasionally breaking free of their gravitational pull. Given such a strongly ingrained pattern of legal thought, international standards or "soft law" concepts of normativity floating free of state and judiciary, are problematic. ${ }^{15}$

\section{International Financial Standards}

\footnotetext{
${ }^{13}$ See Cally Jordan, Cadbury Twenty Years on, University of Melbourne Legal Studies ReSEARCh PaPer, available at: http://papers.ssrn.com/sol3/papers.cfm?abstract_id=2099820.

${ }^{14}$ See generally, Nils JANSEn, The MAKING OF LEGAl Authority, Non-LeGislative CodifiCATION IN Historical and Comparative Perspective (2010).

${ }^{15}$ And, yet, interestingly enough, the concept of self-regulation in the modern financial world finds its strongest national expression in the United States. Like the jury trial, self regulation of the financial industry (the exchanges and intermediaries) is a legacy of 18thC England.
} 
During the global financial crisis, the realisation came, too late, that international capital markets were the purveyors of systemic risk and financial chaos; however, they remain much understudied and misunderstood. "Soft law" solutions, at least those taking the form of international financial standards, were no panacea for what ailed the global financial system.

However, international financial standards had surged to prominence in the wake of the Asian financial crisis of 1997-1998 with the creation of the Financial Stability Forum (FSF). ${ }^{16}$ The role of the FSF was to promote financial stability across national borders and provide an early warning system, identifying potential weaknesses or "vulnerabilities" in national financial systems, with a view to preventing a repetition of the localized financial chaos of 1997. The development of international standards for financial and other commercial regulation and the implementation by the IMF and The World Bank of the Financial Sector Assessment Program or "FSAP" (designed to monitor and assess financial stability on a country by country basis) were two of the initiatives associated with the FSF.

That the FSF was a failure is patently obvious. It has been relegated to the dustbin of history with little ado. The global financial crisis revealed its inadequacies and those of its instrumentalities: international standard setting and financial sector assessment initiatives. Was the approach of the FSF, and its uncritical reliance on a hodgepodge of international standards, in the assessment of the stability of financial systems, fundamentally flawed?

\section{A. The Role of the FSF and the FSAP}

\footnotetext{
${ }^{16}$ For a more detailed critique of the Financial Stability Forum and the use of international financial standards by the IMF and The World Bank in the Financial Sector Assessment initiative, see Cally Jordan, The Dangerous Illusion of International Financial Standards and the Legacy of the Financial Stability Forum, 12 SAN DiEgo InT'L L. J. 333 (2011)
} 
The FSF was caught unawares by the global financial crisis, ${ }^{17}$ although it was purportedly purpose built to detect "vulnerabilities" in financial systems and serve as an early warning system. Masses of information had been collected by bodies such as the IMF and The World Bank pursuant to the FSF- mandated FSAP initiative, but to no avail. It is hard to escape the conclusion that the FSAPs, conducted on a country by country basis using various international standards, were asking the wrong questions or failing to interpret properly the information collected.

The widespread adoption of these international financial standards with their top down approach and riddled with assumption, and their use as indicators of potential financial instability, should have been put into serious question by this financial crisis. The promotion of simplistic, high level, "solutions" to complex and deep-rooted structural problems in various parts of the global financial system is a search for a "quick fix", and doomed to failure. $^{18}$

The financial crisis though raised serious doubts as to the utility of these exercises and painfully highlighted the ineffectiveness of the FSF. As Arner and Taylor point out, the crisis put into question the international "soft law" approach and the workings of "policy networks."19

Implementation of the FSF agenda focused primarily on the use of the FSAP, the financial sector assessments conducted by the IMF in developed economies, and jointly by the IMF and The World Bank, in developing economies. The mandate was to identify "vulnerabilities" in financial systems, on a country by country basis, with a view to

\footnotetext{
17 With the benefit of hindsight, of course, there were the prescient few who saw it coming. "The banking world ignored Gillian Tett when she predicted the credit crisis two years ago", Laura Barton, On the Money, THE GUARDIAN, Oct. 31, 2008; available at: http://www.guardian.co.uk/business/2008/oct/31/creditcrunch-gillian-tett-financial-times (last viewed August 11, 2010).

18 "Admittedly, the G20 has entrusted the Financial Stability Board with the mission of monitoring the standard-setting activity and has mandated the Basel Committee, IOSCO and the IAIS (among others) with the task of developing new rules. However, this choice seems more a quick-fix than a sustainable strategy. It will neither preserve state unity on the international stage, nor solve the issues of circumvention of national and regional democratic processes." Id. at 108.

${ }^{19} I d$. at 4 .
} 
nipping financial crises in the bud. In particular, priority was to be given to systematically important countries. The FSF identified 12 international standards to be used in the process of "benchmarking" or "rating" a financial system. ${ }^{20}$

20

"The 12 standard areas highlighted here have been designated by the FSF as key for sound financial systems and deserving of priority implementation depending on country circumstances. While the key standards vary in terms of their degree of international endorsement, they are broadly accepted as representing minimum requirements for good practice. Some of the key standards are relevant for more than one policy area, e.g. sections of the Code of Good Practices on Transparency in Monetary and Financial Policies have relevance for aspects of payment and settlement as well as financial regulation and supervision.

Area

Standard

Issuing Body

\section{Macroeconomic Policy and Data Transparency}

\begin{tabular}{|c|c|c|}
\hline $\begin{array}{l}\text { Monetary and } \\
\text { financial policy } \\
\text { transparency }\end{array}$ & $\begin{array}{l}\text { Code of Good Practices on Transparency in Monetary and } \\
\underline{\text { Financial Policies }}\end{array}$ & IMF \\
\hline $\begin{array}{l}\text { Fiscal policy } \\
\text { transparency }\end{array}$ & $\underline{\text { Code of Good Practices on Fiscal Transparency }}$ & $\mathrm{IMF}$ \\
\hline Data dissemination & $\begin{array}{l}\text { Special Data Dissemination Standard / } \\
\text { General Data Dissemination System }^{1}\end{array}$ & IMF \\
\hline \multicolumn{3}{|c|}{ Institutional and Market Infrastructure } \\
\hline Insolvency & $\underline{\text { Insolvency and Creditor Rights }} \underline{2}$ & World Bank \\
\hline $\begin{array}{l}\text { Corporate } \\
\text { governance }\end{array}$ & Principles of Governance & OECD \\
\hline Accounting & $\underline{\text { International Accounting Standards (IAS) }}{ }^{3}$ & IASB 4 \\
\hline Auditing & International Standards on Auditing (ISA) & IFAC 4 \\
\hline \multirow[t]{2}{*}{$\begin{array}{l}\text { Payment and } \\
\text { settlement }\end{array}$} & $\begin{array}{l}\text { Core Principles for Systemically Important Payment Systems } \\
\text { Recommendations for Securities Settlement Systems }\end{array}$ & CPSS \\
\hline & & CPSS/IOSCO \\
\hline Market integrity & $\begin{array}{l}\text { The Forty Recommendations of the Financial Action Task Force / } \\
\text { 9 Special Recommendations Against Terrorist Financing }\end{array}$ & FATF \\
\hline
\end{tabular}


The FSAPs produced a veritable gold mine of data over time. ${ }^{21}$ Unfortunately, some of the data is of dubious reliability and quality. There are several reasons for this. The international standards themselves are not of the same caliber. Among the 12 international standards chosen by the FSF there is overlap, duplication and inconsistency. The methodology of the FSAP process was in a constant state of flux. The teams conducting the FSAPs varied in expertise and sophistication. Querelles de chapelle $^{22}$ between the IMF and The World Bank were not unheard of.

Nevertheless, the data accumulated was impressive; the difficulty has been that it cannot be used in a narrow, scientific way, given its deficiencies. Rather, it needs a kind of qualitative interpretation which has not always been possible. Some of the observations, with hindsight, appear spot on. Iceland was identified as vulnerable as far back as 2002 . The importance of supervision and risk assessment of large, complex financial institutions was also recognized early on. Difficulties with some of the standards, such as

\section{Financial Regulation and Supervision}

Banking supervision Core Principles for Effective Banking Supervision

BCBS

Securities regulation $\underline{\text { Objectives and Principles of Securities Regulation }} \quad$ IOSCO

$\begin{array}{ll}\text { Insurance } & \text { Insurance Core Principles }\end{array}$

supervision

Financial Stability Board, Compendium on Standards; available at: http://www.financialstabilityboard.org/cos/key_standards.htm (last viewed August 16, 2010).

${ }^{21}$ This huge volume of data does not seem to find its way readily into the academic literature, although several people at the IMF, in particular, Jennifer Elliott, have laudably been publishing papers making use of the data. See, e.g., Ana Carvajal \& Jennifer. Elliott, The Change of Enforcement in Securities Markets: Mission Impossible" (Int'l Monetary Fund Working Paper No. 09/168, 2009), available at http://ssrn.com/abstract $=1457591$.

22 The expression refers to pointless internal disputes and rivalries within an organization. 
the IOSCO Objectives and Principles of Securities Regulation, were noted. ${ }^{23}$ However, given the volume of data and its variable quality, important observations may have been lost in the "noise"

\section{B. Inadequacies of the FSAP Experience}

Most importantly though, the FSAPs were sometimes asking the wrong questions. Some international standards failed to differentiate among financial markets in different parts of the world, or to recognize the stratification of any one particular market. Financial markets, even internal domestic ones, are not monolithic. Most ironically, for standards billing themselves as "international", many of the standards employed completely missed the international and cross-border aspects of financial markets. This was due to the fact that many of the so-called "international" standards were simply reheated domestic regulation, which did not look to international dimensions of an issue.

The proliferation of codes and standards used in the FSAP process also proved problematic. The standards vary greatly in their origins, level of sophistication degree to which they represent a truly international consensus. They continue to jostle uneasily against each other, demonstrating overlap and generating inconsistencies. Some international standards, such as International Financial Reporting Standards, had been decades in the making by large, international teams of financial experts. Others, such as the OECD Principles of Corporate Governance 1999, had been cobbled together; they were brand new and untested, as well as not representing any meaningful international consensus. However, by grouping together these 12 sets of international standards under the umbrella of the FSAP process, the FSF gave equal, and perhaps unwarranted, legitimacy to all.

Inadequate integration of the results also diminished their relevance. As the "ratings" of countries on various standards began to circulate publicly, it became possible for

${ }^{23}$ The IOSCO Objectives and Principles were not designed to identify systemic risk; rather, until the recent amendments in June 2010, they focused on traditional, one might even say outdated, investor protection mechanisms and market regulation institutions. 
countries to "game" the system, by enacting legislation or adopting measures that would "tick the boxes" without necessarily being of any effect. ${ }^{24}$

As well, the voluntary nature of the FSAP process was problematic. As of the date of the 2006 IMF evaluation, "some 20 to $25 \%$ of countries that are 'systemically important' and/or have vulnerable financial systems - two key criteria endorsed by the IMF and The World Bank Boards - have not been assessed."25 Again as of 2006, four systemically important countries in particular stood out: Turkey, Indonesia, China, and most importantly of all, the United States. ${ }^{26}$

In reacting to criticism that it did not see the global financial crisis coming, the IMF identified the failure of the US to volunteer for an FSAP as a major factor. ${ }^{27}$ The US, for its part, had justified its objections to participating in the FSAP, by invoking the heavy burden such an assessment would place "on the scarce resources of the [IMF]". ${ }^{28}$

The essentially domestic focus of the FSAP process has also been singled out for criticism. Although "contagion" had been at the heart of the Asian financial crisis which led to the creation of the FSF and the FSAPs, the FSAP process ignored cross-border implications. As the 2006 IMF evaluation diplomatically put it: ““'Greater efforts by the

\footnotetext{
${ }^{24}$ CuRtis J. Milhaupt \& Katharina Pistor, LAW AND CAPITALiSM: What CORPORATE CRISES REVEAL ABout LEGAL SYSTEMS AND ECONOMIC DEVELOPMENT AROUND THE WORLD [PAGE AND CITE] (2008). See also Cally Jordan, The Conundrum of Corporate Governance, 30 Brook. J. Int'l L. 983 (2005) on Germany's introduction of a voluntary code of corporate governance.

25 Int'L Monetary Fund IndeP. Evaluation OfF., Report on the Evaluation of the Financial Sector ASSESSMENT PROGRAM (2006), at 7, available at http://www.imf.org/external/np/ieo/2006/fsap/eng/pdf/report.pdf. A subsequent review, THE Financial Sector Assessment Program after Ten Years - Experiences and Reforms for the Next Decade, August 28, 2009, appeared in September 2009; available at: http://www.imf.org/external/np/pp/eng/2009/082809B.

26 Turkey subsequently volunteered and the US finally permitted an FSAP to be conducted, in the wake of the global financial crisis.

27 "The Fund has also deflected criticism of its failure to predict the crisis. Because the United States refuses to be subject to an IMF Financial Sector Assessment Program (FSAP), Managing Director StraussKahn argues, the Fund cannot be responsible for a lack of supervision. The FSAP is one of the IMF's main supervisory instruments, and it was not employed in the United States during the lead-up to the crisis". Laurie Glapa, The IMF faces post-crisis criticism, Center for International Finance and Development at the University of Iowa College of Law, Oct. 15, 2009; available at http://uicifd.blogspot.com/search/label/IMF (last viewed August 11, 2010). ${ }^{28}$ Bossone, supra note 30.
} 
IMF to distil common cross-country messages from the various FSAP exercises would be welcome". ${ }^{29}$

The difficulties associated with execution of the FSAP program were exacerbated by the assumptions operating below the surface of some of the international standards. ${ }^{30}$ Some "international" standards are not international at all, but rather reheated domestic, often US domestic, law. The weakness, in this case, is that such standards are riddled with the hidden assumptions and deficiencies of their country of primary origin. And where that country of origin is the United States, implementing such standards (as is the ultimate goal of the FSAP exercise) may mean adopting inappropriate and suboptimal regulatory approaches.

Take, for example, the IOSCO Objectives and Principles of Securities Regulation (the IOSCO Principles), one of the 12 international standards mandated by the FSF, and referred to on several occasions above. Originally formulated in 1998, in the shadow of the Asian financial crisis, the IOSCO Principles were backward looking, taking as their point of departure the institutions, regulatory framework and market structures of the United States, as they existed in the mid-1990s, even then based on antiquated 1930s regulation.

The IOSCO Principles, because they looked to the US markets and regulation of an earlier and rapidly vanishing era, subsumed the hidden assumptions of that time and place, assumptions which lie deeply buried in their originating conditions, and are rarely explicitly acknowledged. First, there is the 1930s emphasis on retail investors and equity trading. Derivatives, of course, were not on the radar screen (for one thing, they do not come under the regulatory purview of the US SEC), and debt markets virtually ignored (derivatives are usually structured as debt instruments). The "unregulated" or private placement market (wherein hedge funds lurk) were also ignored, having received perfunctory treatment in the 1930s. Securities were still pieces of paper in the 1930s, and

\footnotetext{
29 Int'L Monetary Fund IndEP. Evaluation OFF, supra note 21 at 11. 30 Putting aside for the moment International Financial Reporting Standards and the BIS Capital Adequacy standards which have a long history behind them.
} 
the US regulation continued to play catch up in terms of recognizing the implications of the electronic age. Faith in self-regulatory market institutions remained a deeply entrenched notion and the efficient market hypothesis (a theory now somewhat battered by the crisis) formally acknowledged in US securities legislation. ${ }^{31}$ Finally, U.S. regulation was, and is, notoriously domestically focused.

These features of U.S. securities regulation shine through the IOSCO Principles. They were also the areas of weaknesses, in terms of where the global financial crisis exerted its greatest pressures.

Even the revisions to the IOSCO Principles announced June 10, 2010, while adding eight new principles "based on the lessons learned from the recent financial crisis and subsequent changes in the regulatory environment", 32 do not revisit the original 30 principles and their underlying assumptions. Importantly, the eight new principles do recognize that the "financial markets which IOSCO members regulate, or may be exempt from regulation, can be the mechanism by which risk is transferred within the financial system" (emphasis added). ${ }^{33}$ Unregulated markets finally appear on the radar screen, and the markets themselves (not just institutions) are recognized as systemically important. $^{34}$

Nevertheless, the original thirty IOSCO Principles remain untouched, an example of path dependency in action perhaps. IOSCO has been working around them, addressing significant issues outside the original IOSCO Principles, in new initiatives and reports, as well as by the addition of the eight new principles. However, the assumptions underlying

\footnotetext{
31 See, eg., §2(b) of the Securities Act of 1933: "Consideration of Promotion of Efficiency, COMPETITION AND CAPITAL FORMATION. Whenever pursuant to this title the Commission is engaged in rulemaking and is required to consider or determine whether an action is necessary or appropriate in the public interest, the Commission shall also consider, in addition to the protection of investors, whether the action will promote efficiency, competition, and capital formation".

32 Infra note 29.

33 Press release, Global Securities Regulators adopt new principles and increase focus on systemic risk, IOSCO/MR/10/2010, Montreal, June 10, 2010; available at: http://www.iosco.org/news/pdf/IOSCONEWS188.pdf (last viewed August 20, 2010) ${ }^{34}$ Criticism of the IOSCO Principles is not, in any way, to suggest that IOSCO itself has been a flawed initiative. Quite to the contrary. IOSCO has been a resounding success. Its significance to international capital markets has been growing by leaps and bounds and its members increasingly convinced of the importance of its mission. IOSCO saw the crisis coming and continues to produce topical and informed reports on a wide variety of timely issues,
} 
the eight new principles are different ("regulation" has dethroned both the "efficient market" and "self-regulation"), thus creating certain internal tensions within the enlarged set of principles

But the IOSCO Principles, old and new, remain at the heart of the FSAP exercise. Which brings us back to contagion and predictability. The FSF and the FSAPs did not address contagion issues. Neither did they predict the global financial crisis. They were asking the wrong questions, looking in the wrong directions and, blinded by the glare of international standards, failed to appreciate the complexity and diversity of financial markets and the problems posed by their regulation. ${ }^{35}$

\section{International Commercial Practice and Soft Law}

The experiences of the last fifteen years have demonstrated the difficulties associated with the use of international financial standards. It is hard to escape the conclusion that the debate itself as to the "soft law" nature of international financial standards may be simply beside the point. Certainly, different legal traditions demonstrate different levels of openness and receptivity to international norms which do not derive from state authority and are not subject to national judicial enforcement. The problems associated with international financial standards may stem, not from their "soft law" nature, but rather from their substance and sources: assumption riddled, reheated national law from which are forged into top-down, one-size-fits-all "international" standards.

This is not how the world of international commercial law and finance operates and may explain why the "soft law' discourse in international finance appears so strangely remote

\footnotetext{
${ }^{35}$ The financial industry too seems prepared to welcome an approach which is less reliant on top-down, assumption-riddled, one-size-fits-all international standards. "When everyone is suffering from what appears to be the same shock, the desire to implement a co-ordinated response is high, and because of that desire, the ability is stronger. When everyone is starting to recover, the desire to co-ordinate is inevitably lessened, and as a result it will be more difficult. Luckily, this is probably a good thing....G20 members and their leaders have been very wise in the past 12 months. The G20 creation itself is a fantastic development. But let's not require it always to have its members do the same thing at the same time." Jim O'Neill, Financial Times, Sept. 18, 2009 at 9.
} 
from the daily grind of international commercial practice, where the discourse is largely unknown.

International commercial practitioners engage in a constant balancing of risks, in an admittedly uncertain world. Instinctively cognizant of the dynamism and layered complexity $^{36}$ of legal systems, international practitioners engage in multi-perspective analyses and redundancy in expression and execution.

They do not much think about state authority or judicial enforcement in going about their business. Their analyses are granular; a reference to "international financial law" would evoke bewilderment, as being devoid of meaning. The efforts of international practitioners are focused on promoting effectiveness; concerns as to judicial enforcement are far down the list.

International project finance demonstrates many of these characteristics. Large projects will entail the creation of a virtually autonomous legal framework in which the project operates, especially in emerging economies where there may be little formal written law to begin with, and faint hope of judicial enforcement. A vast construct of contract, thousands of pages of detailed provisions, will link project managers, suppliers, subcontractors, private financiers, sovereign governments, multilateral development banks and financial institutions such as the World Bank and MIGA. Internal panels of experts may be constituted in advance to resolve issues which inevitably arise, precluding even resort to external international commercial arbitration. Multiple choices of law may be applicable to various aspects of the transaction.

Take the case of the huge Nam Theun hydroelectric project in Laos (supported in part by The World Bank and MIGA), for example. ${ }^{37}$ Laos is a small, poor, landlocked country with a population of six and a half million people and a GDP per capita in 2010 of less than US\$2500. Nam Theun 2, or NT 2 as it is known, required US\$330 million in equity

\footnotetext{
${ }^{36}$ See discussion in Schlesinger et Al., Comparative LaW: CaSes, Text, Materials (6 $6^{\text {th }}$ ed. 1998). at 28889.

37 The project began commercial operations in March 2010.
} 
and US\$920 million in debt financing. At the time of signing in 2005, it was the largest private sector cross-border power project and the largest private sector hydroelectric power project financing in the world.

The primary choice of law for the thousands of pages of project finance contracts was Laotian law. $^{38}$ Laos is noted neither for the sophistication of its legislative framework nor the high level skills of its judiciary. But on the other hand, there was clearly little expectation among the dozens and dozens of signatories that there would ever be recourse to either Laotian law or its courts.

Where there was no Laotian law available for application, English law was a fallback. It was quite uncertain though as to where Laotian law left off and English law would pick up. But again, there was little expectation that recourse to any formal law or international commercial arbitration, for that matter, would eventuate.

However, as a precautionary measure, the entire stack of contractual documentation was carted off to the national assembly of Laos and enacted into "law", a somewhat symbolic gesture more than anything and readily accomplished in a one party state. The point to note here is the redundancy and recourse to multiple forms of normativity, characteristic of international finance. Little store is set by formal legislation or enforcement by the courts. Like those tiny ships setting sail from European ports in the sixteenth century in quest of faraway fortunes, the entire endeavour is fraught with uncertainty and is an exercise in calculated risk taking. The objective of all concerned is a practical one; to make it work.

There appears to be a huge chasm between the gritty world of international finance in action and the lofty realm of international financial standard setting. But perhaps in this disconnect between theory and practice lie clues to the normative forces at work in international financial markets. The more one considers the world of international finance, the more obvious become the outlines of centuries old customs and practices, an international merchant law, the ghostly outlines of the lex mercatoria

\footnotetext{
38 The Government of Laos was a party to many of the contracts and acted in various capacities. Where sovereigns are involved, the use of their domestic law, at least notionally, is often required.
} 


\section{International Capital Markets and the Lex Mercatoria}

\section{A. What is lex mercatoria}

Interest in lex mercatoria as a subject of intellectual inquiry waxes and wanes; it is a notoriously slippery concept, with numerous, divergent meanings. Some dispute its existence $^{39}$ but the "romance" of the law merchant, ${ }^{40}$ a phrase coined by Wyndham Bewes in 1923, continues to casts a powerful spell according to Hatzimihail. ${ }^{41}$ There are several generally cited operative concepts traditionally attributed to the lex mercatoria: harmony and equitability, mutual confidence and good faith, the binding force of ordinary undertakings (oral contracts) of merchants, self-regulation deriving from its own needs and experiences, expediency and expeditiousness. ${ }^{42}$ Goode points to the certainty and consistency of practice, reasonableness, notoriety and co-normativity with mandatory law. ${ }^{43}$ And, lex mercatoria, having preceded the nation state, was inherently international, or perhaps a better word would be, anational.

Ralf Michaels has recently provided a useful summation of the some of the various senses in which the term has been used. ${ }^{44}$ He looks at lex mercatoria in its linear, chronological manifestations. The "ancent lex mercatoria" of the Middle Ages was a "transnational set of norms and procedural principles established by and for commerce in (relative) autonomy from states". 45

As the rise of nation states, and written codes and legislation, crowded out (or subsumed) this lex mercatoria, it supposedly dissipated. Then there was the "renaissance of the idea as a 'new lex mercatoria' in the $20^{\text {th }}$ century, an informal and flexible net of rules and arbitrators establishing a private international commercial law." ${ }^{46}$ Most recently,

\footnotetext{
${ }^{39}$ Emily Kadens, The Myth of the Customary Law Merchant, 90 TeXas LAW Rev. 1153 (2012) 40 Wyndham Bewes, The Romance of The Law Merchant (Sweet \&Maxwell, London, 1923). ${ }^{41}$ Nikitas Hatzimihail, The Many Lives- And Faces- of Lex Mercatoria: History as Genealogy in International Business Law, 71 LAW AND CONTEMPORARY PROBlEMS 169 (2008).

42 Disputes settled "between the ebb and flow of the tide", or "from tide to tide". See, among others, Charles Kerr, The Origins and Development of the Lex Mercatoria, 15 VA.LAW REvIEW 350 (1928-29)

${ }^{43}$ Roy Goode [cite]

${ }^{44}$ Ralf Michaels, The True Lex Mercatoria: Law Beyond the State, 14 Indiana J. of Global Legal STUDIES 447 (2007)

45 Id., 448.

${ }^{46} I d$.
} 
according to Michaels, there has emerged a "'new new lex mercatoria', which moves from an amorphous and flexible soft law to an established system of law with codified legal rules (first and foremost the UNIDROIT Principles of International and Commercial Law) and strongly institutionalized court-like international arbitration.",47

The search for one comprehensive body or theory of modern lex mercatoria has bedeviled much theoretical scholarship in the area, but what if the answer is much simpler. There are numerous distinct varieties of lex mercatoria, sharing certain persistent communalities with specialized characteristics evolving over the centuries, a Darwinian lex mercatoria, if you like. Berger has written of the separate sets of transnational commercial law for specialized areas of international business, such as the lex petrolia or lex sportiva. ${ }^{48}$ Could it be that international capital markets are supported by a large body or bodies of lex mercatoria that has persisted over centuries? Does a largely unrecognized and unacknowledged, but powerful, lex financeria, rooted in the distant past, undergird modern capital markets?

\section{B. The Persistence of the lex mercatoria}

Interestingly, it is the "ancient" lex mercatoria, in the sense of " a transnational set of norms and procedural principles established by and for commerce in (relative) autonomy from states", that shines through the workings of modern international capital markets. The notion of "self-regulation" for example, which is enshrined in the IOSCO Principles, can be traced straight back to medieval guilds and the City of London.

\section{The City of London and Self Regulation}

It is not an accident that self-regulation of financial institutions and intermediaries has found its strongest expression, at least until recently, in the United Kingdom. ${ }^{49}$ Even well into the 19thC, the financial center of the United Kingdom and, arguably the world's most important international financial center, was the City of London, usually

47 Id.

44 Klaus Peter Berger, The New Law Merchant and the Global Market Place - A 21 ${ }^{\text {st }}$ Century View of Transnational Commercial Law, available at: www.trans-lex.org/000002.

49 The United States inherited it from the UK in pre-revolutionary times, and it persisted through the centuries as it served the interests of iinance well. 
simply referred to as "the City" 50 The City of London predates the Magna Carta (1215 CE). "[T]he national importance that was attached to the ancient liberties and franchises of London, may be estimated by the fact that it was made an express provision of the Magna Charta itself, that the City of London should have all its ancient liberties and customs...". 51

The City of London, home to merchants and traders, has been special for centuries, if not millennia. "The time-honoured City of London, like many other cities which flourished under the auspices of Imperial Rome, seems to have actually constituted, during the lengthened and obscure period of the Middle Ages, a species of independent selfgovernment, contrasting by the comparative enlightenment of its municipal institutions, with that dark feudal system, whose iron chains bound down the Nations of Europe to the exclusive service of warfare or the priesthood." ${ }^{, 52}$ In the City, commerce reigned.

Not only were the franchises and customs of the City recognized as carrying immunity from the burdens of the feudal system (and the common law generally), but the immunities later extended even to acts of Parliament. "Now it must be borne in mind, that when a general statute, silent as to the City of London, passes both Houses of Parliament, for effecting a reform in any branch of the law as to which there happens to exist a peculiar custom of the City of London, it is at least doubtful whether the statute will prevail within the limits of the City. It is laid down in some text-books, that the City customs are of such force that they shall prevail against a general Act of Parliament either using negative or positive words. Lord Coke, in numerous passages, lays it down, 'that the special customs of the City shall prevail against the general law of the land"',53

Customs which can face down acts of Parliament are powerful indeed, so it should not be surprising that vestigial, and perhaps not so vestigial, elements persist in the City of

\footnotetext{
50 The City of London is a geographically defined area and a corporation dating back to the 12 thC. "The Guildhall body, though nominally the Corporation of London, are restricted both for good and evil within the small space of 600 acres, and to a population of about one-tenth of the whole Metropolis of London". The City of London Corporation Inquiry, 19 L.REV.\& Q.J.BRIT\&FoREIGN JURISPRUDENCE 389, 424, 1853-February1854.

51 Id., 392.

$52 I d ., 391-92$.

53 Id., 401-02.
} 
London. Much of the autonomy commented upon in the report from which the above excerpts are taken may have dissipated in the years since $1853 .{ }^{54}$ However, even up to the financial reforms of the late 20thC and the creation of the now doomed Financial Services Authority (2000), autonomy and self-regulation defined the financial services industry in the City of London.

\section{The Case of Oral Contracts}

The use and recognition of oral contracts is another characteristic of a lex mercatoria. The nudum pactum, ie the contract without formalities, did not exist in Roman law but was, in the interests of commercial expediency (and the generalized illiteracy of the age), recognized among merchants and traders. ${ }^{55}$ Napoleon's 1807 Code de commerce brought together much of the pre-existing commercial customs and practices, which would include various aspects of lex mercatoria, including the recognition of oral contracts among merchants. To this day, France makes a distinction between "civil" contracts (among non-merchants, and governed by the Code civil), and commercial contracts (among merchants and governed by the Code de commerce).

Commercial contracts may be proven more simply than ordinary, or "civil", contracts. Ordinary (civil) contracts for over Euro 1500 must be made in writing ${ }^{56}$, which now includes electronic forms of writing. ${ }^{57}$ Commercial contracts are exempt from this requirement with article L110-3 of the Code de commerce providing that commercial agreements may be proven by any means unless otherwise provided by law. ${ }^{58}$ By way of contrast, the later German civil code (Bürgerliches Gestzbuch or BGB) posits a universal principle of consensual contract and the commercial code does not need to

\footnotetext{
${ }^{54}$ The City of London Corporation Inquiry, id., recounted perceived abuses associated with the autonomy of the City. "The present members of the Corporation of London...seem to have imbibed the notion that in order to divert a reform of the present system, and the substitution of one which should really serve the purposes of a Metropolitan municipality, it would suffice to urge that there is no ground for the imputation of 'moral turpitude or personal corruption'." This was in contradistinction to their predecessors in the eighteenth century where "[h] eavy tavern expenses were allowed, the cause of charity and education was neglected, and publicity avoided". Id., 426-27. 55 [cite]

56 Art. 1341 Civil Code (Fr).

${ }^{57}$ Art. 1316 Civil Code (Fr).

58 The law does otherwise provide in some instances, such as for contracts for the sale of businesses.
} 
make an exceptions for merchants or traders. ${ }^{59}$ Oral contracts among merchants are thus enforceable, as are any other contracts.

Oral contracts among merchants were also recognized in the City of London. Given the existence of a recognized commercial practice, the 1677 Statute of Frauds $^{60}$ (requiring a writing for the enforceability of certain contracts) did not apply in the City of London. This was explicitly acknowledged in the case law even as to the transfer of land. "Ever since the Statute of Frauds, the conveyance of estates and interests in land, except by an instrument in writing has been deemed to be prohibited by law. But here, again, the custom of London conflicts; and the old Guildhall law provides that a bargain and sale for valuable consideration of houses or lands in London by word only is sufficient to pass the same [See on this point, 2 Jurist, 675; Busher v. Thompson, 16 Law J.C.P.59] (emphasis in the original)." 61

So it is no coincidence that the motto of the London Stock Exchange (established in 1801 ) is the famous "Dictum meum pactum" - "My word is my bond", or more literally, "My word is my agreement".

\section{Modern Finance and the Lex Mercatoria}

But is this of any relevance to the world of modern finance? ${ }^{62}$ The rivalry between Parliament and the City of London persists to this day, underpinning the self-regulatory approach that is so characteristic of Anglo-American finance. Symptomatic of the continued rivalry is the UK's reputation for "light touch" financial regulation. The UK touted light touch regulation in the decade leading up to the 2008 global financial crisis as the great advantage of London as an international financial center. ${ }^{63}$

\footnotetext{
59 See arts. $125,126 B G B$.

60 Now largely repealed in the UK [cite to 1954 statute].

61 [cite]

62 "Investment bankers", as understood in the United States, are "merchant bankers" in London, an indication of the persistence of the institutions and patterns of thought associated with merchant law (the literal translation of lex mercatoria). Historically, merchant bankers trace their origins to Jewish bankers specializing in international finance in Italy (bills of exchange, underwriting, financings, futures, grain guarantees, credit and insurance). They sat among the merchants and used the techniques of the silk route for providing long distance financing. [source]

63 Not surprisingly, less is now heard about light touch regulation.
} 
Oral contracts are also still a hallmark of modern finance. Berger maintains that "the morality and mutual trust" represented by 'my word is my bond' even today is a more generalized characteristic of "international business which turns the contractual promise into a categorical imperative". ${ }^{64}$

The London Stock Exchange, whose motto it is, still claims title as the world's premier international capital market. ${ }^{65}$ The City of London has also been home to the swaps and derivatives markets, so maligned in the aftermath of the global financial crisis. The swaps and derivatives markets developed in the 1980s as a "telephone market". 66 Oral, bilateral contracts were entered into over the telephone by specialized traders, relatively few in number. Despite the international reach of these transactions, the traders and much of the trading were geographically concentrated in the City of London. ${ }^{67}$ These contracts were long term (often exceeding ten years in duration) and for very large amounts of money, the usual factors militating in favor of written agreements. Despite this, these oral contracts often remained undocumented for months, if not years. Over time, standardized contracts ${ }^{68}$ were developed to support the oral contracts and facilitate subsequent documentation. Radical changes in modern technology did not fundamentally change the nature of the swaps and derivative markets; at least some corners of them remain a telephone market.

Modern finance is full of "closed cells", pockets of professionals repeatedly dealing with each other ${ }^{69}$ in relative, or perhaps total, obscurity. Even the language of modern finance is metaphorically cloaked in darkness, full of "dark pools" and "black boxes". 70 Although conversations among traders are now recorded as a matter of course, the ephemeral nature and intimacy of the human voice plays tricks with the speakers,

\footnotetext{
64 Supra note [ ], 12.

65 Although subject now to competition from a variety of contenders and various forces in the marketplace.

66 The advanced technology of the day.

${ }^{67}$ Although not exclusively.

${ }^{68}$ The ISDA Master Agreements.

69 "Many in the industry describe the interdealer market as acosy club of select banks and brokers, who play by their own rules, fashioned since the early 1970s when the collapse of fixed currencies ushered an era of volatile exchange rates that required a middle man to help banks trade." Michael Mackenzie, Libor probe shines light on voice brokers, FinANCIAL TIMES, February 16, 2012.

${ }^{70}$ It is interesting to note that the lack of transparency of dealings in the City of London was one of the concerns of the 1853 report [title], supra note [].
} 
sometimes resulting in unintended indiscretions (but which only reach the light of day in the event of a major blow-up).

The global financial crisis was obviously a blow-up of major proportions. It exposed the inward workings of the swaps and derivatives markets, among others. But lesser scandals, such as the current one over the manipulation of $\mathrm{LIBOR}^{71}$, also illuminate market practices which usually operate unknown to the general public. In particular, in the LIBOR scandal, the pivotal role of "voice brokers" came to light.

Computers and Bloomberg terminals dominate trading floors, but the human element remains a crucial feature of transacting across derivatives and other parts of the global financial system. This is no better illustrated than by the presence of so-called "voice brokers" who act as middle men for banks trading swaps and other fixed income securities in financial centres that link Asia, Europe and the $\mathrm{US}^{72}$

Working in the interdealer market ${ }^{73}$, voice brokers convey prices to traders by telephone and "squawk boxes"74 although they do use computer screens to display certain other information. The voice brokers usually have several clients and a privileged view of where the market may be heading. "[W]hen a very competitive price enters the market, a voice broker will tell their best account the price before they tell their other accounts."

The persistence of oral transactions in finance would seem to defy the logic of modern communications. But perhaps not. The oral contract in the lex mercatoria may have been faute de mieux, nothing else was available that met the expediency and expeditiousness of commerce (as well as the generalized illiteracy of prior ages). But several other aspects of the oral transaction in commercial dealing likely also persist, ensuring its longevity.

\footnotetext{
${ }^{71}$ Supra,note [68] [Mackenzie FT article]. "Enforcement agencies in the US, Canada, Europe and Japan are investigating whether employees at leading US and European banks colluded to influence where Libor and other key benchmark rates were set, in some cases to profit on interest-rate derivatives linked to the rates....'When you start trying to collude or price fix a benchmark that affects mortgage rates, and the cost of certain car and school loans, it behoves regulators to take a very hard look"'. ${ }^{72} \mathrm{Id}$,

73 "[T] he private arena where only banks trade with each other as they offset positions they have with clients such as hedge funds, money managers and corporations'. Id.

${ }^{74} \mathrm{An}$ indication of how primitive the verbal communications systems were until relatively recently; voices would be distorted and the speakers "squawk".

${ }^{75}$ Supra, note [68][Mackenzie]
} 
The intimacy and immediacy of the human voice obviously contribute to the building of the mutual trust that is characteristic of specialized industries and which is noted by Berger, among others. ${ }^{76}$ This mutual trust develops in the face of rampant self-interest and cutthroat competition. There are self-regulating limits; otherwise the market implodes to everyone's detriment. ${ }^{77}$

Related to the development of mutual trust, is speed and security. Voice negotiation benefits from quick reaction times and opportunities for repositioning, advantages often noted in the context of the "open outcry" exchange model before it finally succumbed to technology. ${ }^{78}$

But perhaps the most intriguing aspect of oral transactions, in addition to their trustinducing nature, is their security. In modern finance, where trades are negotiated over the telephone and squawk boxes, the human voice is key to identifying your counterparty.

Human beings demonstrate a remarkable capacity for voice recognition, especially "active" voice recognition as opposed to "passive" voice recognition. The distinction is based on actually participating in a conversation (a negotiation, for example) as opposed to simply overhearing one. ${ }^{79}$ Interestingly enough, and there may be equally intriguing reasons for this from the point of view of evolutionary biology, “[p]eople's apparent ability to recognize a voice they have heard before can be a [sic] high as $96 \%$ correct (McGhee, 1937) when men recognize women's voices." 80

\footnotetext{
${ }^{76}$ Supra, note [ ][Berger]

77 This aspect of the derivatives markets was graphically illustrated in the recent movie Margin Call [2011], one of the more authentic renditions of a market panic and collapse. The head trader resists pressures from above to completely liquidate a portfolio of "toxic assets" on the basis that such an act would destroy the market itself, as well as the firm on the sell side of the transactions. No one would trade with the seller firm's traders again. The depiction of the frenzied selling is also significant; the transactions, in a volatile and rapidly moving market, are voice trades, where seller and buyer know each other.

${ }^{78}$ Again, see Margin Call for an example oral negotiation and repositioning by traders, as the market slides and prices drop rapidly. Algorithmic trading is lightning fast, of course, but predetermined by the algorithm and thus ultimately less flexible than voice trading.

${ }^{79}$ See, generally, Richard Hammersley and J. Don Read, The Effect of Participation in a Conversation on Recognition and Identification of the Speakers' Voices, 9 LAW AND HUMAN BEHAVIOR 71 (1985).

${ }^{80} I d, .71$. This makes a good case for putting more women on the trading floor; arguably it would increase the rate of voice identification..
} 
The use of voice recognition as a trading device is explicitly acknowledged in both financial industry practices and by their self-regulatory organizations. The interdealer markets are small and clubby, as noted above, so a high degree of voice recognition would be expected among traders and brokers in frequent contact. However, even in the retail brokerage business, voice recognition is remarkably reliable, to the extent that it is incorporated in in-house policies as well as binding industry association rules. ${ }^{81}$ For example, "RBC Dominion Securities' policy and procedures state that we must get verbal confirmation of fax and email instructions before proceeding with a transaction. These RBC DS policies are devised in order to be in compliance with our industry regulator's rules (i.e. the Investment Industry Regulatory Organization of Canada (IIROC))(emphasis added) “ 682

Autonomy from the state, ie. self-regulation, and the legitimacy, perhaps even the imperative, of oral contracting are both characteristics of pockets of modern finance. And although the nature of self-regulation in finance and the purposes to which oral contracts are put have mutated over the centuries, the outlines of the "ancient" lex mercatoria persist. ${ }^{83}$ A resurgence of interest in legal pluralism, the recognition that "law" may emanate from multiple sources and diverse processes, may be moving recognition of operative concepts of lex mercatoria from the "periphery" as Berger calls it, to a position of greater centrality.

81 This insight occurred to the peripatetic author when a long time broker contacted her by voice mail at a summer house, asking for her to call and confirm instructions for reinvesting proceeds of an investment which had just matured. Email and even fax were not sufficient for purposes of the confirmation. The author, having reached the broker by telephone, joked that this must be a vestige from an earlier, less technologically advanced era. However, the broker noted that although it had been many years since he had heard the author's voice [and would have dealt with hundreds of clients in the interim], he had immediately recognized it. Equally, the author had immediately recognized the broker's voice despite the intervening period of many years.

82 Email to the author dated January 25, 2012 from Andras Birkus, RBC Dominion Securities, in the possession of the author. See Guidelines for the review, supervision and retention of advertisements, sales literature and correspondence, IIROC: "Acceptance of orders communicated via email, voice mail, or any other electronic means, other than a dedicated order-entry system, creates a number of risks, such as delays in opening and executing instructions or inadequate instructions being provided by the client. Clients and registered representatives should be strongly discouraged from communicating order instructions via email or voice-mail. Having said that, if they choose to use these methods of communication, clients should be warned of the risks described above." Andras Birkus noted in his email that the IIROC rules established the minimum standard, which individual firm policies and guidelines often exceeded. IIROC is a self-regulatory organization.

83 Berger, supra note [ ]. 


\section{CONCLUSION}

Several intriguing implications arise from viewing international financial markets as being supported by a form, or more accurately, forms of lex mercatoria. Was the global financial crisis triggered, in part, by a breakdown in the operation of lex mercatoria in several crucial sectors of the financial industry?

In his fascinating study of diamond merchants ${ }^{84}$ in New York City, ${ }^{85}$ Barak Richman investigates how it is that a diamond merchant will hand over hundreds of thousands of dollars worth of diamonds against a promise to pay at a later date, essentially a sale on credit. What precludes industry participants from taking advantage of these "extraordinarily lucrative opportunities...to cheat" ${ }^{86}$

The diamond industry, like other specialized areas of finance, spans centuries and continents. ${ }^{87}$ The New York Diamond Dealer Club is modelled on centuries old European diamond bourses, with their trading rules, membership requirements and mandatory industry arbitration. ${ }^{88}$ Diamond merchants have "systematically rejected use of public courts and state created law to enforce contracts and police behavior." 89

There are several factors which Richman identifies as crucial to the diamond merchant industry in New York City. The industry is dominated by small number of merchants, primarily ultra-orthodox Jews, a distinct ethnic community in New York, immediately identifiable by their appearance, voice and manners. The community is bound together by religious, family and commercial ties. The "traditional social structures that pervaded Jewish communities throughout the world before the Enlightenment remain intact". 90 Strong, pervasive, reputational forces operate in multiple dimensions. Industry arbitration publicizes broken promises. Significant, according to Richman, is the importance of the

\footnotetext{
${ }^{84}$ Note the use of the word "merchant".

85 Barak D. Richman, How Community Institutions Create Economic Advantage: Jewish Diamond Merchants in New York, 31 LAW \& SOCIAL InQUIRY 383 (2006).

${ }^{86}$ Id., [383].

${ }^{87}$ Id. [ ]. [Quote description in Richman article].

${ }^{88} \mathrm{Id}$., [ ] ].

${ }^{89} \mathrm{Id}$., [ ] . In fact, recourse to the courts will result in fines or suspension from the New York Diamond Dealers Club and a possible end to a trading career.

${ }^{90}$ Id., [ ].
} 
long view. Mutual trust is fostered by the desire of each merchant "to preserve the opportunity to engage in future lucrative transactions," the grave given the intergenerational nature of the business.

The old face of international finance, of which the diamond industry could be considered a subset, shares some of the same characteristics. "Name and shame" is a venerable regulatory technique of the London Stock Exchange, which itself as an institution, until the very recent past, was modelled, and not coincidentally, along the same lines as the New York Diamond Dealers Club. Investment firms were family firms, partnerships, the business being passed from generation to generation. Homogeneity of ethnic and cultural background was reinforced by the educational and class system in the UK and the closed, clubby nature of the industry. ${ }^{92}$

But twenty-five years ago (at about the same time as derivatives began to appear), all that started to change, for better or worse. The world of finance experienced a cultural and institutional rupture with the past. Stock exchanges demutualized; no more were they private clubs. Investment firms expanded rapidly, both in terms of personnel and geographic reach, abandoning the partnership form. The walls protecting the homogenous, culturally distinct, enclaves of finance were breached. The unspoken assumptions and understandings were confused.. Most significantly, the long term and intergenerational reputational pressures dissipated. Michael Lewis in his [1987] exposé of bond trading on Wall Street described young traders, barely out of university, "blowing up" their clients, by selling them products which would financially implode at a future date. By that time, the young trader, pockets full, would have moved on, leaving the financial carnage behind. ${ }^{93}$

Have the efforts to create international financial standards been an attempt to "fix" or reinvent a lex mercatoria of finance? But by drawing on state, legislative and regulatory

\footnotetext{
91 Id., [ ]

92 The "old" Wall Street demonstrated similar characteristics. Interestingly enough, the institutional structure and characteristics of the financial firms was mirrored in the elite Wall Street law firms which serviced them. The lawyers were drawn from a small circle of elite law schools and constantly interacted with each other. Prior to the internet, transactions were negotiated and structured by means of endless conference calls. Oral undertakings and agreements with respect to deal structure and documentation were scrupulously observed.

93 Liar's Poker, [1987].
} 
models, are they looking in the wrong place. Do we need international financial standards at all, or just better lex mercatoria? Will waves of re-regulation drive the surviving lex mercatoria temporarily into hiding? Or will regulatory impasse, such as that being experienced in the United States, promote the blossoming and transformation of lex mercatoria new corners of the financial world?

There is much explanatory force in viewing international capital markets from the perspective of a lex mercatoria. A better understanding of the normative forces at work, lex mercatoria being among them, can point to better ways of providing oversight and imparting integrity to the international markets.. As Gunther Teubner has noted, lex mercatoria may be "soft law", but it is not weak law. ${ }^{94}$

${ }^{94}$ As cited in Berger, supra note [44] 